Plant Tissue Cult. \& Biotech. 20(1): 81-89, 2010 (June)

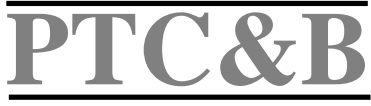

\title{
Micropropagation of Pogostemon cablin Benth. through Direct Regeneration for Production of True to Type Plants
}

\author{
M. Kumaraswamy and M. Anuradha* \\ Padmashree Institute of Management and Sciences, Kommagatta campus, Kengeri, \\ Bangalore- 560060, India \\ Key words: Micropropagation, Direct regeneration, Pogostemon cablin, \\ Organogenesis
}

\begin{abstract}
Multiple shoots from nodal explants of Pogostemon cablin Benth. MS supplemented with $0.5 \mathrm{mg} / \mathrm{l}$ BAP initiated a mean of 45.66 shoots/nodal explant. Within four weeks of initiation, regenerated multiple shoots attained a height of $3.6 \mathrm{~cm}$. Subsequent transfer of these in vitro derived nodal segments onto MS supplemented with BAP and $\mathrm{Kn}(0.5 \mathrm{mg} / \mathrm{l})$, induced a mean of 62.45 shoots. Higher concentration of either BAP or $\mathrm{Kn}$ more than $0.5 \mathrm{mg} / \mathrm{l}$ resulted in callus proliferation and showed hyperhydric shoots with morphological abnormalities. Rooting was readily achieved upon transfer of shoots on half strength MS supplemented with $100 \mathrm{mg} / \mathrm{l}$ activated charcoal. Rooted shoots, following acclimatization in greenhouse, were successfully transferred to soil with $91 \%$ survival. Also shoots regenerated in vitro were directly transplanted to soil and acclimatized. Tissue cultured plants were analyzed for oil content by employing gas chromatography and found that the patterns were similar to mother plants. This confirms the true to type nature of micropropagated plants.
\end{abstract}

\section{Introduction}

Patchouli (Pogostemon cablin Benth.), belongs to Lamiaceae. It is an aromatic plant, native to tropical Asia and widely grown in India, Malaysia, Philippines, Indonesia and Singapore. The patchouli oil, obtained by steam distillation of shade-dried leaves is commercially used in perfumes and cosmetics (Hasegawa et al. 1992, Maheswari et al. 1993). It also possesses anti-insecticidal activities, antifungal and bacteriostatic properties (Kukreja et al. 1990, Yang 1996, Pattnaik et al. 1996). In aromatherapy, it is used to calm nerves, relieve depression and stress. Fibrinolytic and antithrombotic (Sumi 2003, Park et al. 2002) activity of this essential oil is also been reported.

*Rishi Foundation, \#234, 10th C main, 1st Block, Jayanagar, Bangalore-560011.

<swamy.bio@gmail.com>. 
The plant never flowers in India and hence vegetative propagation through stem cuttings is in practice. However, the feasibility of mass production of patchouli through conventional methods has been limited due to recurrence of mosaic virus (Sastri and Vasanth Kumar 1981), root knot nematodes and insect pests. Apart from this, propagation through vegetative cuttings is slow and insufficient for large scale cultivation. Natural variations occurring in this plant may result in yield fluctuations. The rapidness of tissue culture techniques can be advantageous for the continuous provision of plantlet stock for field cultivation (Reddy et al. 2001) and may further complement breeding programmes.

Many authors have envisaged feasibility of mass propagation of high yielding and disease/pathogen resistant patchouli through tissue culture. Patchouli plants regeneration from stem tip, leaf and nodal callus (Meena 1996, Padmanabhan et al. 1981), plant regeneration from protoplasts encapsulated in alginate beads (Kageyama et al. 1995), mass production of virus free plants by in vitro culture and somatic embryogenesis (Kukreja et al. 1990, Rajan et al. 1997) have been reported. Hembrom et al. (2006) has reported the production of true to type plants of Pogostemon heyneanus through dedifferentiated axillary buds. However, there are limited efforts to study direct organogenesis, which supports cultivation by providing true to type plants in large numbers. Hence present study is aimed at establishing suitable protocols for rapid regeneration of patchouli by direct organogenesis using nodal explants. This method can mitigate the problem of non-availability of planting materials to meet the global demand.

\section{Materials and Methods}

Nodal segments were procured from elite Pogostemon cablin Benth. mother plants, maintained at Rishi Herbal Garden, Bangalore, India. All expanded leaves and petioles were removed and the explants were cut into $1-2 \mathrm{~cm}$ length. The explants were washed three - four times in the tap water and treated with liquid soap, teepol for $15 \mathrm{~min}$ followed by thorough washing under tap water. These were then surface sterilized with $0.5 \% \mathrm{HgCl}_{2}$ for $10 \mathrm{~min}$. Rinsing was done five times with sterile distilled water to remove traces of $\mathrm{HgCl}_{2}$ completely. Under aseptic conditions, explants were inoculated on MS, containing $2 \%(\mathrm{w} / \mathrm{v})$ sucrose, supplemented with different concentrations and combinations of $\operatorname{BAP}(0.25,0.5$, 1.0, $2.0 \mathrm{mg} / \mathrm{l})$ and $\mathrm{Kn}(0.25,0.5,1.0,2.0 \mathrm{mg} / \mathrm{l})$ for shoot proliferation and multiplication. The $\mathrm{pH}$ of the medium was adjusted to 5.8 prior to the addition of $0.8 \%$ agar and autoclaved at $121^{\circ} \mathrm{C}, 15 \mathrm{lb}$ pressure for $15 \mathrm{~min}$. All the cultures were incubated at $25 \pm 2{ }^{\circ} \mathrm{C}$ under a $16 \mathrm{hr}$ light and $8 \mathrm{hr}$ dark regimes with a light intensity of 3000 lux provided by cool-white fluorescent tubes. Weekly observations were recorded. In vitro derived shoots from both the explants were 
excised after 30 days and subcultured on to fresh medium with the same concentrations of growth regulators unless otherwise mentioned.

For rooting, $5-6 \mathrm{~cm}$ long regenerated shoots bearing at least four - five internodes were excised and cultured on freshly prepared rooting medium containing MS or half strength MS supplemented with different concentrations of activated charcoal $(100,200 \mathrm{mg} / \mathrm{l})$, IAA and NAA $(0.5,1.0 \mathrm{mg} / \mathrm{l})$. Rooted plantlets were transferred to sterile soilrite in net pots. For direct acclimatization, the in vitro derived shoots with thick stems were cut off and directly transferred to sterile soilrite in net pots. Plantlets were hardened for four weeks in a moisture saturated chamber with $80 \%$ relative humidity and were transferred to pots containing soil : manure : sand $(1: 1: 2)$ under shade condition. The experiments were set up in completely randomized design with different treatments replicated thrice. Twenty cultures were raised for each treatment. Data recorded after 30 days of culture were statistically analyzed and results were presented in Table 1.

Fresh leaves of $P$. cablin were hydrodistilled by a Clevenger-type apparatus. The essential oil was collected and stored at $4^{\circ} \mathrm{C}$ until being analysed for its chemical constituents by gas chromatography (GC).

GC analysis of the oil was performed on Varian 3400 (Varian, Les Ulis, France) with an FID and an electronic integrator. The instrument was fitted with a $30 \mathrm{~m} \times 0.25 \mathrm{~mm}$ non-polar CP-Sil-5-CB-MS column, film thickness $0.25 \mathrm{~mm}$. Oven temperature was programmed from $50-220^{\circ} \mathrm{C}$ at $5^{\circ} \mathrm{C} / \mathrm{min}$, held at $120^{\circ} \mathrm{C}$ for $10 \mathrm{~min}$. Injector and detector temperatures were 250 and $280^{\circ} \mathrm{C}$, respectively. Carrier gas was helium at 16 psi. One $\mathrm{ml}$ of oil dissolved in acetone was introduced into the gas chromatograph with a split mode ratio of $1: 100$. The constituents of the oil were identified by running the reference sample under similar condition.

\section{Results and Discussion}

The nodal explants underwent direct organogenesis when cultured on MS using various concentrations of BAP and $\mathrm{Kn}(0.25,0.5$ and $1.0 \mathrm{mg} / \mathrm{l})$ separately or in combinations. Comparatively BAP showed the strongest effect than Kn in terms of shoot induction. It also increased mean shoot length and shoot weight (Table 1). According to George et al. (2008), BAP is most effective in enhancing shoot multiplication and triggering shoot elongation. The use of MS supplemented with $0.5 \mathrm{mg} / \mathrm{l}$ BAP was best suitable for bud break (Fig. 1a) and resulted maximum number (45.66) of shoots/explant; higher shoot length $(3.6 \mathrm{~cm})$ and fresh weight $(2.94 \mathrm{~g})$ of the shoot without callus induction. The result is in agreement with the findings of Bharati (2002) but contradictory to the findings of Kukreja et al. (1990) and Hembrom et al. (2006), who reported the higher 
requirement of cytokinin (2 $\mathrm{mg} / \mathrm{l} \mathrm{BAP})$ for maximum multiple shoot regeneration in patchouli.

Table 1. Effect of on shoot proliferation from nodal segments of patchouli grown on MS after 30 days of first subculture.

\begin{tabular}{lcccc}
\hline $\begin{array}{c}\text { MS + BAP and Kn } \\
(\mathrm{mg} / \mathrm{l})\end{array}$ & $\begin{array}{c}\text { No. of shoots/ } \\
\text { explant }\end{array}$ & $\begin{array}{c}\text { Length of the } \\
\text { shoots }(\mathrm{cm})\end{array}$ & $\begin{array}{c}\text { Fresh wt. of the } \\
\text { shoots }(\mathrm{g})\end{array}$ & $\begin{array}{c}\text { Callus } \\
\text { formation }\end{array}$ \\
\hline MS (Control) & 13.62 & 1.23 & 1.06 & - \\
MS + 0.25 BAP & 36.66 & 1.73 & 1.42 & - \\
MS + 0.5 BAP & 45.66 & 3.60 & 2.94 & - \\
MS + 1.0 BAP & 20.00 & 1.65 & 1.97 & + \\
MS + 2.0 BAP & 00.00 & 0.00 & 0.00 & + \\
MS + 0.25 Kn & 23.33 & 1.93 & 1.08 & - \\
MS + 0.5 Kn & 34.56 & 2.43 & 2.87 & - \\
MS + 1.0 Kn & 21.53 & 2.23 & 2.44 & - \\
MS + 2.0 Kn & 00.00 & 0.00 & 0.00 & + \\
F- value & $49.72^{*}$ & $5251.03^{*}$ & $6239.80^{*}$ & \\
SEM & 2.84 & 0.01 & 0.01 & \\
CD & 8.46 & 0.04 & 0.04 & \\
\hline
\end{tabular}

*Significant at 5\% level. + : Callus induction, - : No callus formation.

However, BAP at $0.5 \mathrm{mg} / \mathrm{l}$ when used for subsequent subcultures resulted in callus, indicating the elevation of endogenous hormonal levels. Hence though initiation was made on medium supplemented with $0.5 \mathrm{mg} / \mathrm{l} \mathrm{BAP}$, multiplication was better evidenced on $0.25 \mathrm{mg} / \mathrm{l} \mathrm{BAP}$. As the concentration of cytokinins was increased beyond $0.5 \mathrm{mg} / \mathrm{l}$, it resulted in decrease in number of shoot buds coupled with callus proliferation.

The decrease in shoot production at higher concentration of BAP may be due to the inhibition of organogenesis and induction of callus proliferation. Patchouli is a very sensitive plant and it expresses its morphogenetic potentiality even at very low concentrations of cytokinins. Shoot proliferation was satisfactory on MS supplemented with $0.25 \mathrm{mg} / \mathrm{l} \mathrm{BAP}$ and $0.5 \mathrm{mg} / \mathrm{l} \mathrm{Kn}$ separately. However, Kn has no significant effect on multiple shoot regeneration but played a role in increasing the length and strength of shoots. The combination treatment $(0.5 \mathrm{mg} / \mathrm{l}$ BAP along with $0.5 \mathrm{mg} / \mathrm{Kn}$ ) was found to exhibit highest frequency of shoot multiplication $(62.45 \%)$. The highest mean shoot length $(5.2 \mathrm{~cm})$ and mean fresh weight of the shoot $(5.07 \mathrm{~g})$ was also evidenced in the same treatment (Table 2). The efficacy of BAP over Kn, when used singly, and in combination has been demonstrated for the axillary bud proliferation in many medicinal plants of Lamiaceae like Mentha spicata and Lavendula viridis (Hirata and Kukreja 1990, Dias and Nickell 2002). Higher effect of the combination of BAP and Kn may be 
due to the synergy of cytokinins as reported in Rollinia mucosa and Solanum surrattense (Figueiredo 2001, Pawar 2002). The above result clearly indicates that combination of BAP and $\mathrm{Kn}$ is a better choice for patchouli as it significantly exhibited better morphogenetic response in terms of multiple shoot regeneration, length of the shoots and production of biomass (Fig. 1b).

Table 2. Effect of combination of cytokinins on elongation of shoots regenerated from primary node cultures of patchouli grown on MS after 30 days.

\begin{tabular}{|c|c|c|c|c|c|}
\hline \multicolumn{2}{|c|}{$\begin{array}{c}\text { Concentrations } \\
(\mathrm{mg} / \mathrm{l})\end{array}$} & \multirow{2}{*}{$\begin{array}{l}\text { Shoot } \\
\text { length } \\
(\mathrm{cm})\end{array}$} & \multirow{2}{*}{$\begin{array}{c}\text { Number } \\
\text { of multiple } \\
\text { shoots }\end{array}$} & \multirow{2}{*}{$\begin{array}{l}\text { Fresh weight } \\
\text { of the shoots } \\
\text { (g) }\end{array}$} & \multirow[t]{2}{*}{$\begin{array}{c}\text { Callus } \\
\text { formation }\end{array}$} \\
\hline BAP & $\mathrm{KN}$ & & & & \\
\hline 0.0 & 0.0 & 0.21 & 13.14 & 1.10 & - \\
\hline 0.25 & 0.25 & 1.95 & 62.66 & 2.46 & _- \\
\hline 0.5 & 0.25 & 4.65 & 61.33 & 4.67 & _ \\
\hline 1.0 & 0.25 & 1.66 & 22.66 & 1.86 & + \\
\hline 0.25 & 0.5 & 3.31 & 41.66 & 3.06 & _- \\
\hline 0.5 & 0.5 & 5.20 & 62.45 & 5.07 & _ \\
\hline 1.0 & 0.5 & 2.05 & 21.37 & 2.35 & + \\
\hline 0.25 & 1.0 & 2.32 & 23.00 & 2.96 & _ \\
\hline 0.5 & 1.0 & 2.67 & 42.10 & 4.14 & _- \\
\hline $1.0^{\prime}$ & 1.0 & 1.92 & 21.33 & 2.35 & + \\
\hline \multicolumn{2}{|c|}{ F value } & $1531.7^{*}$ & $354.1^{*}$ & $8141.7^{*}$ & \\
\hline \multicolumn{2}{|l|}{ SEM } & 0.01 & 0.98 & 0.01 & \\
\hline \multicolumn{2}{|l|}{$\mathrm{CD}$} & 0.03 & 2.93 & 0.03 & \\
\hline
\end{tabular}

*Significant at $5 \%$ level. + : Callus induction, - : No callus formation.

The effect of strength of MS with and without activated charcoal, IAA and NAA at different concentrations on rhizogenesis was studied (Table 3). Among the treatments, half strength MS was found enough for better rooting. This is in conformity with the results obtained by Bharati (2002) in patchouli. However, it was not possible to induce high frequency of rooting $(93.33 \%)$ when shoots implanted on half strength MS with $100 \mathrm{mg} / \mathrm{l}$ activated charcoal. Mean number of roots/shoot $(15.23)$ and root length $(6.23 \mathrm{~cm})$ was found to be superior among all other treatments (Fig. 1c). This is the first report of its kind in patchouli. Activated charcoal is an antioxidant and known to induce rhizogenesis in Decalepis hamiltonii (Obul et al. 2001) and Annona cherimoya (Padilla and Encina 2004). This is because it provides darkness in the medium, which is essential for rooting. The result obtained by using half strength MS and activated charcoal is superior to the results obtained by using auxins. Both IAA and NAA were shown to induce rooting with varying degrees, however not suitable for patchouli as both the auxins invariably triggered callus proliferation. The results of Meena 
(1996) support the usage of auxins for rhizogenesis in patchouli which is in contrary to the present observation. This suggests that although the addition of auxins is beneficial for rooting, their use is not essential in patchouli. The similar result is reported in Ulmus species (Paula et al. 2008).

Table 3. Effect of various concentrations IAA, NAA and AC on rooting of proliferated shoots of patchouli cultured on MS.

\begin{tabular}{lccc}
\hline $\begin{array}{c}\text { MS (strength) } \\
\text { auxin }(\mathrm{mg} / \mathrm{l})\end{array}$ & $\begin{array}{c}\text { Root induction } \\
(\%)\end{array}$ & $\begin{array}{c}\text { Mean number of } \\
\text { roots/shoots }(\mathrm{cm})\end{array}$ & $\begin{array}{c}\text { Mean root } \\
\text { length }(\mathrm{cm})\end{array}$ \\
\hline MS (1/2) & 91.01 & 13.00 & 5.40 \\
MS (1/2) + IAA (0.5) & 71.31 & 12.10 & 5.13 \\
MS (1/2) + IAA (1.0) & 64.33 & 13.66 & 5.16 \\
MS (1/2) + NAA (0.5) & 65.66 & 14.06 & 5.43 \\
MS (1/2) + NAA (1.0) & 61.00 & 13.78 & 5.66 \\
MS (1/2) + AC (100) & 93.33 & 15.23 & 6.23 \\
MS (1/2) + AC (200) & 92.66 & 15.00 & 6.10 \\
MS & 82.12 & 11.20 & 5.10 \\
MS + IAA (0.5) & 51.00 & 11.66 & 5.14 \\
MS + IAA (1.0) & 67.66 & 12.12 & 5.23 \\
MS + NAA (0.5) & 63.33 & 12.00 & 5.45 \\
MS + NAA (1.0) & 55.33 & 12.01 & 5.50 \\
MS + AC (100) & 90.66 & 13.21 & 5.76 \\
MS + AC (200) & 85.00 & 13.00 & 5.80 \\
F value & $664.43^{*}$ & $56.51^{*}$ & $60.23^{*}$ \\
SEM & 0.34 & 0.35 & 0.04 \\
CD & 1.00 & 1.13 & 0.12 \\
\hline
\end{tabular}

* Significant at $5 \%$ level.

This will add to the cost effectiveness of the protocol used for micropropagation of patchouli. After four weeks, $89 \%$ of in vitro derived plants were directly acclimated (Fig. 1e). This is comparable with the results of in vitro rooting. Present results lead to the conclusion that formation of in vitro roots prior to acclimatization is not needed. The same conclusion is reported by Paula et al. (2008) and Zong and Nian (1995) that in vitro rooting could be eliminated to reduce time and cost.

In vitro raised plantlets were transplanted to soilrite in net pots (Fig. 1d). During the early hardening phase, maintenance of $80 \%$ relative humidity in the chamber showed $91 \%$ plantlets survival. After four weeks of hardening, the plantlets were transferred to pots filled with sand : soil : manure $(2: 1: 1)$ under shade. Gradual transfer of the established plants to the sunlight was ideal for tissue culture derived patchouli plants in the field (Fig. 1f) rather than a direct 
transfer to sunlight, which caused wilting of plants and charring of leaves. Similar observations are recorded by Meena (1996).
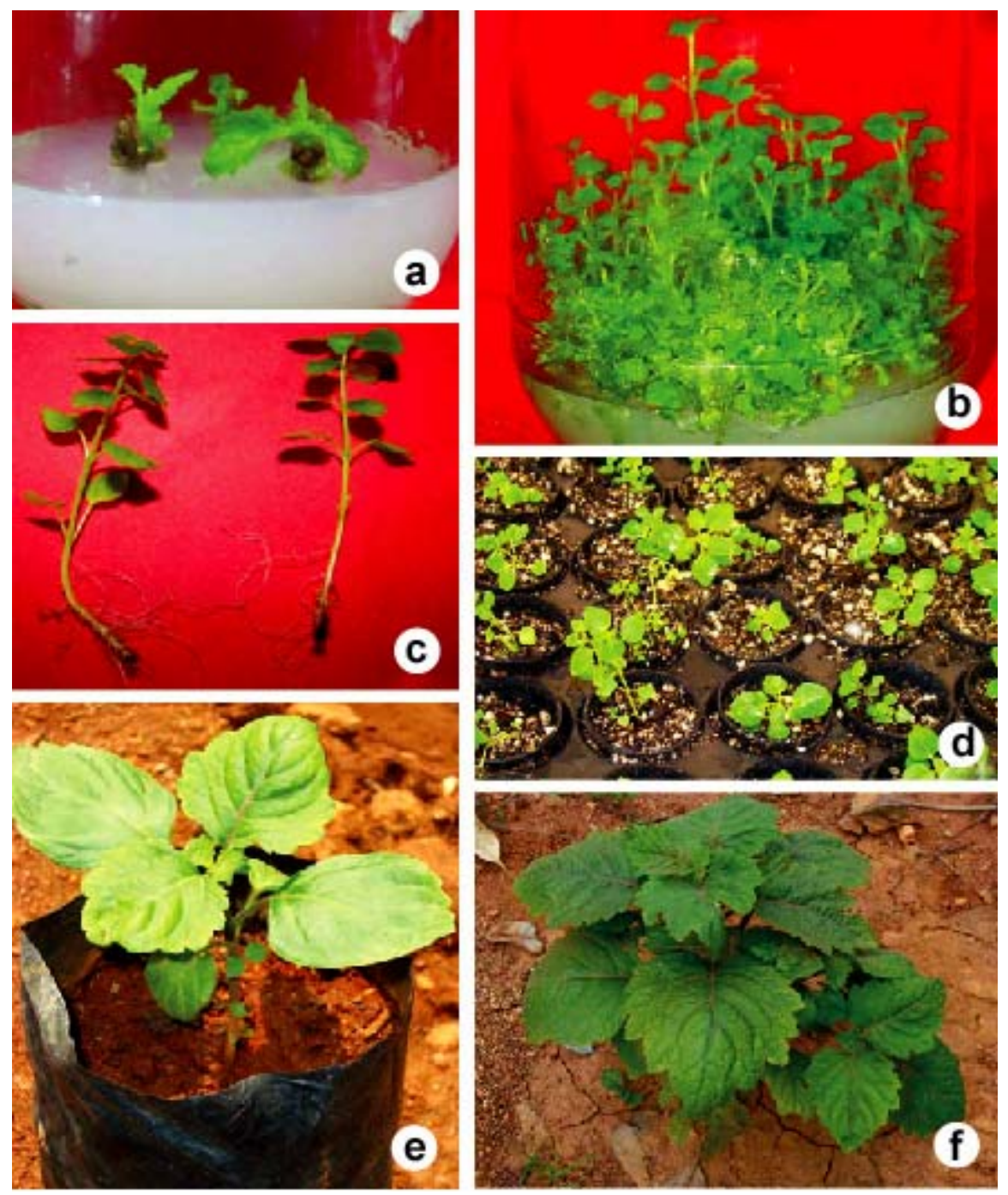

Fig. 1. In vitro regeneration of Pogostemon cablin from nodal explants. a. Induction of shoots in four weeks of culture on MS $+0.5 \mathrm{mg} / \mathrm{l} \mathrm{BAP}$. b. Multiple shoot regeneration from nodal segments on MS $+0.5 \mathrm{mg} / \mathrm{l} \mathrm{BAP}$ and $0.5 \mathrm{mg} / \mathrm{l} \mathrm{Kn}$. c. Rooting of shoots on MS (half) + activated charcoal $(100 \mathrm{mg} / \mathrm{l})$. d. In vitro raised plantlets transplanted to soilrite in net pots. e. Directly acclimated plantlet in the soil. f. In vitro regenerated plant in the field.

All the regenerated plants grown for four months were similar in leaf morphology, plant height and number of branches per plant. The patchouli oils were extracted from the leaves of in vitro grown plants and their GC patterns were compared. There were no differences in the chemical composition among 
the regenerants with all sequiterpenes present in the oil. The oil yield was found to be $0.30 \%(\mathrm{v} / \mathrm{w})$ of fresh weight. Patchouli alcohol at $30.31 \%$ was found to be the predominant component in the oil. Plantlets were also compared with those of the mother plants. No differences were observed in the oil composition. This confirms the true to type nature of the micropropagated plants.

\section{References}

Bharati N (2002) Biotechnology in commercial production of patchouli in North Eastern region. In: Patchouli; National Workshop on Commercialization of patchouli in North Eastern region held at Guwahati, Assam. NEDFC and NHB, pp. 46 -51.

Dias MC and Nickell GL (2002) Rapid multiplication of Lavandula viridis L. through in vitro axillary shoots proliferation. Plant Cell Tiss. Org. Cult. 68: 99-102.

Figueiredo SFL (2001) Micropropagation of Rollinia mucosa (Jacq.) Baill. In Vitro Cell. Dev. Biol. Plant. 37: 4 71- 475.

George EF, Hall MA and Klerk GJD (2008) Plant propagation by tissue culture: Vol. 1. The background. Third Edition, Springer Publisher: Dordrecht; London.

Hasegawa Y, Tajima K, Toi N and Sugimura Y (1992) An additional constituent occurring in the oil from a patchouli cultivar. Flavour and Fragrance Journal 7: 333-335.

Hembrom, Manoj E, Martin KP, Patchathundikandi, Suneesh K and Madasser Joseph Y (2006) Rapid in vitro production of true to type plants of Pogostemon heyneanus through dedifferentiated axillary buds. In vitro Cell. Dev. Biol. Plant. 42(3): 283-286.

Hirata T and Kukreja AK (1990) Volatile monoterpenoids constituents of the plantlets of Mentha spicata produced by shoot tip culture. Phytochemistry 29: 955-959.

Kageyama Y, Honda Y and Sugimura Y (1995) Plant regeneration from patchouli protoplasts encapsulated in alginate beads. Plant Cell Tiss. Org. Cult. 41(1): 65-70.

Kukreja AK, Mathur AK and Zaim M (1990) Mass production of virus free patchouli plants (Pogostemon cablin (Blanco) Benth. by in vitro culture. Trop. Agri. 67: 101-104.

Maheshwari ML, Vasantha KT, Neelam S and Chandel KPS (1993) Patchouli - An Indian perspective. Indian Perfumer. 37: 9-11.

Meena M (1996) Regeneration of Patchouli (Pogostemon cablin Benth.) plants from leaf and node callus, and evaluation after growth in the field. Plant Cell Repro. 15: 991-994.

Obul RB, Giridhar P and Ravishankar GA (2001) In vitro rooting of Decalepis hamiltonii. Wight and Arn, an endangered shrub, by auxins and root promoting agents. Curr. Sci. 81(11): 26-29.

Padilla MG and Encina CL (2004) Micro propagation of adult Cherimoya (Annona cherimoya). In vitro Cell. Dev. Biol. Plant. 40(2): 210-214.

Padmanabhan C, Sukumar S and Sreerangaswamy SR (1981) Patchouli plants differentiated in vitro from stem tip and callus cultures. Curr. Sci. 50: 195-197.

Pattnaik S, Subramanyam VR and Kole C (1996) Antibacterial and antifungal activity of ten essential oils in vitro. Microbios. 86: 237-246.

Park E, Yoon HK and Kim DH (2002) Antithrombotic activity of sunghyangjunggisan. Natural Product Science 8(2): 71-75. 
Paula C, Alexandra S, Armando C and Conceicao S (2008) Aprotocol for Ulmus minor Mill. Micropropagation and acclimatization. Plant Cell Tiss. Org. Cult. 92(1): 113-119.

Pawar PK (2002) A technique for rapid propagation of Solanum surrattense Burm. F. Indian. J. Biotechnol. 1: 201-204.

Rajan GB, Shakila A and Rajasekaran LR (1997) Mass propagation of Pogostemon patchouli through somatic embryogenesis. South Indian Hort. 45: 45-49.

Reddy PS, Rodrigues R and Rajasekharan R (2001) Shoot organogenesis and mass propagation of Coleus forskohlii from leaf derived callus. Plant Cell Tiss. Org. Cult. 66: 183-188

Sastri KS and Vasantha KT (1981) Yellow mosaic of patchouli (Pogostemon patchouli) in India. Curr. Sci. 50: 767-768.

Sumi H (2003) Fibrinolysis-accelerating activity of the essential oils and Shochu aroma. Aroma Research 4(3): 264-267.

Yang D, Michel Mandin, Andriamboavonjy Poitry Chaumont and Mellet C (1996) Antifungal and antibacterial properties in vitro of three patchouli oils from different origins. Acta Botanica Gallica. 143(1): 29-35.

Zong M C and Nian QS (1995) Micropropagation of mature Siberian elm in two steps. Plant Cell Tiss. Org. Cult. 41(2): 197-199. 